\title{
The Ethics of Uncle Tom's Children
}

\section{Citation}

Shelby, Tommie. 2012. “The Ethics of Uncle Tom's Children.” Critical Inquiry 38 (3) (March): 513532.

\section{Published Version}

doi:10.1086/664549

\section{Permanent link}

http://nrs.harvard.edu/urn-3:HUL.InstRepos:11899739

\section{Terms of Use}

This article was downloaded from Harvard University's DASH repository, and is made available under the terms and conditions applicable to Open Access Policy Articles, as set forth at http:// nrs.harvard.edu/urn-3:HUL.InstRepos:dash.current.terms-of-use\#OAP

\section{Share Your Story}

The Harvard community has made this article openly available.

Please share how this access benefits you. Submit a story.

Accessibility 


\title{
The Ethics of Uncle Tom's Children
}

\author{
Tommie Shelby
}

\section{LIVING WITH INJUSTICE}

How should one live? This central philosophical question can be separated into at least two parts. The first concerns the conduct and attitudes morality requires of each of us. The second is about the essential elements of a worthwhile life; it's about what it means to flourish, which includes meeting certain moral demands but is not exhausted by this. Answering this two-prong question traditionally falls within the sub-discipline of ethics, broadly construed. Philosophers have also sought to explain what makes a society just or good, to specify the values and principles by which we are to evaluate institutional arrangements and political regimes. This is the traditional domain of political philosophy. This essay addresses a question that arises where ethics and political philosophy meet.

Philosophers that attempt to answer the question "How should one live?" typically abstract away from the concrete sociopolitical circumstances within which individuals make their lives, circumstances that, as it turns out, may be shaped by serious injustices. This kind of idealization has its place. It is often productive to start with ideal theory, where we assume individuals are acting under reasonably just background conditions, using what we learn to better understand what choices we ought to make in our less than ideal, real lives. But there are vexing ethical questions that can be answered only if we theorize them against the background of 
societal injustice. The question within non-ideal theory that I want to take up is how one should live under conditions of serious societal injustice. I am particularly concerned to understand how members of oppressed groups ought live when the prospects for overcoming their oppression are uncertain or dim.

As with ideal theory, answering the question of how the oppressed ought to live is not limited to specifying their moral obligations. It also entails explaining what a life well lived in the face of oppression would involve. Obviously full flourishing (on almost any account of what this comes to) is out of reach for the oppressed. Flourishing while carrying the burdens of gross injustice is a barely intelligible idea. But eking out a quiet, minimally decent life-“just getting by," as they say-does not exhaust the options.

In an effort to find some measure of satisfaction in life under unjust conditions, the oppressed may try to acquire material comfort, seek love and friendship, express themselves through art and religion, and attempt to achieve personal goals despite the obstacles that have been placed unfairly in their path. In addition, a life well lived must include living (and also dying) with dignity. This means that although one's life is structured by shame-inducing conditions one nevertheless lives in a way one can be proud of. Or, if this is too much to ask, then perhaps we might say that the oppressed should make life choices they would have no reason to feel ashamed of. To put the question succinctly: what would constitute a morally responsible and dignified response on the part of the oppressed to intractable, oppressive conditions? The answer to this question constitutes what I 
will call "the ethics of the oppressed."

Depending on the social conditions that obtain, the ethics of the oppressed gives rise to two types of imperatives. On the one hand, there are life choices one should make when it appears possible to overcome, mitigate, or evade the injustices one faces; and then there are life choices one should make when freedom or even relief seems unattainable. So, then, there is an ethic of resistance aimed at liberating the oppressed from injustice and an ethic of resistance aimed at living with dignity despite insurmountable injustice.

I am convinced that there is such a thing as the ethics of the oppressed. I must admit however that I have found it difficult to clearly articulate its contentthat is, its specific requirements and permissions. Its exact contours are elusive and complex, and not readily systematized. But in this regard I have found it helpful to reflect on Richard Wright's collection of short stories Uncle Tom's Children (1938). ${ }^{1}$ These novellas shed light on the meaning of this dual-sided ethic, insights which can be built upon.

A number of philosophers have sought to better understand our moral lives through the study of literature. ${ }^{2}$ There are, however, many perils involved in using literary fiction for ethical reflection (e.g., conflating imaginary people with real people, treating the fictional work as evidence for moral claims, believing naively

\footnotetext{
1 Richard Wright, Uncle Tom's Children (New York: HarperPerennial, 1993).

2 See, for example, Martha Nussbaum, Love's Knowledge: Essays on Philosophy and Literature (New York: Oxford University Press, 1990); Bernard Williams, Shame and Necessity (Berkeley: University of California Press, 1993); Colin McGinn, Ethics, Evil, and Fiction (Oxford: Oxford University Press, 1997); and Robert Pippin, Henry James and Modern Moral Life (Cambridge: University of Cambridge Press, 2000).
} 
that reading fiction will make you a better person, or falsely presuming a close reading of a compelling character can tell us how we should live). ${ }^{3}$ Nevertheless, I think Wright's stories contain and convey real moral wisdom-I dare say "moral truths" - which, despite these pitfalls, I aim to draw out and defend.

\section{LESSONS FROM THE CHILDREN OF “UNCLE TOM”}

Perhaps largely because of James Baldwin's influential and infamous critical essay, “Everybody's Protest Novel" (1945), Richard Wright's early fiction has come to be understood as "protest fiction." ${ }^{4}$ Baldwin's ostensible target in that essay is Harriet Beecher Stowe's classic Uncle Tom's Cabin (1852). Thus, this charge of being a mere protest writer might seem to apply most strongly to Wright's Uncle Tom's Childrenthough Baldwin mainly had Native Son (1940) in mind. The label "protest fiction" might give the impression that the primary aim of these short stories must be to arouse moral outrage and sympathy, to lead the reader to conclude that racism and Jim Crow are, as Baldwin sarcastically remarks, "perfectly horrible." Such an approach to literature, Baldwin argues, smacks of crude sentimentality and ressentiment, and it implicitly accepts the dehumanizing categories of the oppressor in a vain attempt to "prove" the humanity of the oppressed.

\footnotetext{
3 For discussion, see Candace Vogler, "The Moral of the Story," Critical Inquiry 34 (2007): 5-35.

4 James Baldwin, "Everybody's Protest Novel," Partisan Review (June, 1949). Reprinted in James Baldwin, Notes of a Native Son (Boston: Beacon Press, 1955), pp. 13-23.
} 
However, I propose to read Uncle Tom's Children, not as protest literature, but as philosophical fiction. ${ }^{5}$ In particular, I interpret the text as, fundamentally, a discourse on ethics, one that uses the short-story genre as its medium. Uncle Tom's Children is not principally concerned to envision a new society in which racism and segregation no longer exist and freedom and justice obtain. Nor is its objective to recount and decry the awful crimes that whites committed against blacks in the segregated South. Nor, finally, is the point to motivate northern white liberals to aid their degraded darker fellows below the Mason Dixie line. Rather, the stories are about how the oppressed, from the standpoint of ethics, should respond to the injustices that weigh so heavily upon them. Specifically, I think Wright is attempting to sketch a set of values that he believes the oppressed ought to live by as they struggle to survive, and hopefully to overcome, their oppression.

Support for this reading can be found in Wright's manifesto, "Blueprint for Negro Writing" (1937), in which he discusses the responsibilities of black writers and actually anticipates Baldwin's critique. ${ }^{6}$ He writes: "Today the question is: Shall Negro writing be for the Negro masses, moulding [sic] the lives and consciousness of

\footnotetext{
5 Others have highlighted the philosophical ideas expressed in these short stories, though mainly to emphasize, not the stories' moral content, but either existentialist themes (e.g., the expression of freedom through personal rebellion, the individual's lonely search for meaning in a disenchanted world, the inevitability of suffering, and the liberation that comes with the voluntary acceptance of death) or tenets of Marxism (e.g., the significance of class unity and interclass conflict, the false promises and trivial rewards of bourgeois life, and the explanatory power of materialist theories of society and history). See, for example, George E. Kent, "Richard Wright: Blackness and the Adventure of Western Culture," CLA Journal 12 (1969): 322-343; James R. Giles, "Richard Wright's Successful Failure: A New Look at Uncle Tom's Children," Phylon 34 (1973): 256-266; Steven J. Ruben, "The Early Short Fiction of Richard Wright Reconsidered," Studies in Short Fiction 15 (1978): 405-410; and B. Eugene McCarthy, "Models of History in Richard Wright's Uncle Tom's Children," Black American Literature Forum 25 (1991): 729-743.

6 Richard Wright, "Blueprint for Negro Writing," New Challenge 2 (1937). Reprinted in Richard Wright Reader, ed., Ellen Wright and Michel Fabre (New York: Da Capo Press, 1997), pp. 36-50.
} 
those masses toward new goals, or shall it continue begging the question of the Negroes' humanity?"7 This is obviously a rhetorical question, buttressed by his later statement, "a new role is devolving upon the Negro writer. He is being called upon to do no less than create values by which his race is to struggle, live and die."8 Wright may not have practiced what he preached. It is also possible that though he sought to play the role of "creator" of black values, he unwittingly fell back into the old mode of Negro writing that he was so critical of and that elicited the disdain of Baldwin. Yet I want to suggest that at least with Uncle Tom's Children, he did try, and with considerable success, to exemplify a set of black values. Or rather, as I prefer to read him, he makes vivid and attractive a set of values that the members of oppressed groups, including blacks, should adopt.

\section{A. Killing the Uncle Tom Within}

Let's begin with the epigraph from Uncle Tom's Children:

The post Civil War household word among Negroes—“He's an Uncle Tom!"which denoted reluctant toleration for the cringing type who knew his place before white folk, has been supplanted by a new word from another generation which says:- "Uncle Tom is dead!"9

\footnotetext{
7 Ibid., p. 40.

8 Ibid., p. 43; emphasis added.

${ }^{9}$ Wright, Uncle Tom's Children, p. xxx.
} 
This interpretation of the epithet "Uncle Tom" is not intended to be faithful to the famous character from the Stowe novel. The original Uncle Tom may possess some of the vices that Wright is concerned to expose, but the novel's main character is not an exemplar of the ethical failings of the oppressed. Instead, Wright's interpretation of the vice of being an Uncle Tom is rooted in black folk wisdom. It is the "cringing type" of black person that has died, will die, or should die. And in fact the protagonists in Wright's stories exhibit, though always imperfectly, this new ethic of transgressing the boundaries of "the Negro's place." These persons are defiant in the face of blatant white racism, even if this means facing dire consequences, including imminent death. ${ }^{10}$ Most importantly for Wright, Uncle Tom's children-this new breed of blacks-overcome their fear and fight back when unjustly treated. Yet in many of his characters the old ethic of fear still lingers, and they often stumble because of it, typically with tragic, even catastrophic, consequences. The new ethic is merely nascent rather than fully mature. Uncle Tom is not quite dead, then, but dying.

In each of the five short stories, there is at least one protagonist-Big Boy, Silas, Mann, Reverend Taylor, and Sue-who takes a defiant stand against his or her oppressors. However Wright's new ethic is not so militant that it demands one never submit to injustice or humiliation. There are moments in each story when a main character will acquiesce to injustice to avoid serious physical harm, to protect loved

\footnotetext{
10 The symbolic and political significance of death and killing in Wright's stories is perceptively and thoroughly examined in Abdul JanMohamed, “Rehistoricizing Wright: The Psychopolitical Function of Death in Uncle Tom's Children," in Richard Wright, ed. Harold Bloom (New York: Chelsea House, 1987), pp. 191-228.
} 
ones, to live to fight another day, or to die a more meaningful death at a later time.

These are permissible choices within the ethics of the oppressed. Moreover, "fighting back" is not just about overcoming or reducing oppression. To be sure, the oppressed can value fighting back because of the good it produces, both in terms of reducing undeserved suffering and in terms of weakening the power of the dominant group. But fighting back can also be its own reward.

The focus of Wright's stories is on the difficult everyday ethical choices that blacks faced under Jim Crow. Yet the wrong choice was often made, he implies, because blacks had been socialized into a culture of docility. The disposition to submit to injustice is difficult to overcome, and resisting the urge to acquiesce does not always come naturally to the oppressed. Against the background of this entrenched ethos of fear, Wright sought to dramatize the formidable ethical challenges that blacks confronted under the Southern regime of segregation. Although he sympathizes with the oppressed as they struggle to survive under manifestly unjust conditions, he sees his task as urging his fellow blacks to abandon the ethics of fear in favor of his new ethics of the oppressed.

There are at least two broad imperatives for members of oppressed groups that can be discerned in Uncle Tom's Children: seek solidarity with others similarly oppressed and maintain your self-respect. ${ }^{11}$ Corresponding to these two virtues are two vices: disloyalty and servility. Wright is particularly concerned to highlight how

${ }^{11}$ In Kinnamon's reading of the stories in the collection, he highlights Wright's emphasis on the need for unified collective action against oppression, what he calls "militant collectivism" in contrast to bourgeois individualism. See Keneth Kinnamon, The Emergence of Richard Wright: A Study in Literature and Society (Urbana: University of Illinois Press, 1972), pp. 82-117. 
undignified, and sometimes blameworthy, it is to be disloyal to the other members of one's oppressed group and to be servile in the face of oppression.

In the second edition of Uncle Tom's Children (1940), Wright makes explicit his aims behind the collection in an opening essay "The Ethics of Living Jim Crow." The point of this autobiographical sketch is to describe real-life examples of persons who fail to observe the two ethical imperatives of self-respect and solidarity. He rejects the "Jim Crow wisdom" his mother seeks to impart to him, an ethic that counsels one to never fight or resist whites, to accept that whites have the right to use violence against blacks who refuse to recognize the legitimacy white supremacy, and to be grateful that whites give blacks a chance to make lives for themselves at all. This is an ethic that encourages blacks to give into their fears, an ethic of cowardice and cynicism. Wright tells a series of anecdotes from his life that explain how he learned this ethic and to illustrate its main features. Each is interesting and revealing, but here I'll briefly mention one.

Wright gives an account of how two white men he worked for beat a black woman bloody for not paying her bill at their clothing store. A police officer observes the assault yet does nothing. In the aftermath, seeing the woman staggering along the street in obvious pain, the officer arrests her for being drunk in public. When Wright tells his black coworkers about the incident, instead of being outraged or expressing empathy, one of them says, "Shucks! Man, she’s a lucky bitch! 
... Hell, it's a wonder they didn't lay her when they got through."12 Interestingly, Wright does not portray himself here as defiant in the face of such cruelty. In fact, he emphasizes that he watched in silence as his employers dragged and kicked the woman and that he did not object when they later joked about it in his presence.

The ethics of Jim Crow required not only that blacks comply with its unjust norms but that they not complain about, let alone protest, the gross unfairness of these norms. Indeed, white violence and malice were largely reserved for those who refused to accept their low station in the social order. The ethics of Jim Crow demanded submission with a smile. Resentment and fighting back were not tolerated. Perhaps the most insidious aspect of this ethos is that it structured the consciousness of the oppressed, leading individual blacks to police themselves and each other and thereby making them unwitting contributors to their own degradation. Notwithstanding the almost overwhelming power of the system of racial segregation, Wright believes there is hope for his people to overcome their condition, provided they work together to kill the Uncle Tom that lives within each of them.

\section{B. "Bright and Morning Star"}

I think that Wright's implicit praise for solidarity and self-respect among the oppressed can be found in each of the five stories in the collection-from Big Boy's and Silas's open defiance despite the prospect of violent, even lethal, retaliation to

\footnotetext{
12 Wright, Uncle Tom's Children, p. 8.
} 
Taylor's ultimate realization that only unity among "the people" can liberate them from oppression. One can also find in each of the stories places where disloyalty and servility are condemned, and sometimes punished—from the betrayals of the "black Judas" Deacon Smith to Mann's repeated failures to stand up for himself. To illustrate these ideas, I will focus on the last story in the volume, "Bright and Morning Star," which, in keeping with the literary arc of the collection as a whole, exemplifies the new ethic in its most realized form.

There are four principal characters: Sue, a black woman; her adult son, Johnny-Boy, who is a committed communist; Reva, a young white woman who is in love with Johnny-Boy; and Booker, a white man who has recently joined the local Communist Party. It's a rainy day in Memphis. Sue is worrying about Johnny-Boy, who is out organizing white and black communists for a meeting the next day. Wright describes Sue as having drawn strength and solace from the Christian religion in the past. Her sons, however, had urged her to reject this outlook-which they believed counseled accommodation to injustice-for a communist vision. And Sue had come, reluctantly, to accept this new vision. Though biblical notions still held some attraction, Sue believed that the liberation of black folk through interracial, class-based solidarity had replaced her previous commitment to spiritual salvation through faith in Christ.

Reva arrives, telling Sue that the sheriff has found out about the meeting planned for the next day and that someone has to warn the comrades that the meeting is off; she then leaves. When Johnny-Boy later arrives Sue tells him the 
distressing news. Mother and son argue about whether whites are as trustworthy allies as blacks, with Sue confident that it must have been a white person who sold out and Johnny-Boy maintaining his faith in interracial working-class unity. JohnnyBoy leaves to warn his comrades.

Later that night, Sue is awakened by the sound of several men rummaging through her kitchen. She confronts them: "Yuh white folks git outta mah house!"13 Strong words are exchanged between Sue and the men, including the sheriff, who asks for the whereabouts of her son and about the Party meeting. Sue refuses to give any information. The sheriff slaps Sue twice for being "sassy," knocking her to the ground. As the men prepare to leave, Sue shouts: "Yuh didn't git whut yuh wanted! N yuh ain gonna nevah git it!"14 Here, Wright describes Sue as feeling pride and freedom in being defiant, and drawing strength from letting her son go, knowing he would almost certainly be killed by these men. She wanted the men to know that she knew they were treating her and other blacks unjustly and that she was no longer willing to put up with it without a fight. In response to Sue's outburst, the sheriff beats her mercilessly, with punches and kicks, until she's unconscious.

She awakens to the presence of Booker. Though he expresses concern for her welfare, Sue instinctively distrusts and fears him. (Fear is her overwhelming emotion in this episode, and, interestingly, 'Fear' is the title of Book One of Native Son.) Booker tells her that Johnny-Boy has been caught and asks her to tell him the names of the other members of the Party so he can warn them. Sue is torn. On the 
one hand, she has real doubts about his trustworthiness; on the other, she wonders whether Johnny-Boy is right when he insists that distrusting whites is foolish and impractical. Ultimately, she relents and tells him who the comrades are. Booker leaves in haste.

Moments later, Reva returns and announces to Sue that Booker is, in fact, a "Judas." Sue gets a gun and heads for the woods to cut off Booker. Again, Wright describes Sue's inner thoughts: while deliberating about what to do, she reflects on the meaning of her life of fear. She recognizes that the old ethos still lived within her, and that it was this that led her to tell Booker about the comrades against her better judgment. She is torn by competing loyalties. She thought that her commitment to struggle for justice here and now had fully replaced her longing for divine redemption in the hereafter, but it had not.

She arrives at the gathering of the red squad, her gun concealed in a sheet. Booker has not gotten there yet. She is met by several white men, who taunt and try to humiliate her. She sees Johnny-Boy, who is tied up and has clearly been tortured. The sheriff promises Sue that if she gets Johnny-Boy to reveal the names of his comrades, he will be allowed to leave town. She adamantly refuses and thus is forced to watch as the men torture her son further. Finally, Booker arrives, eager to reveal the names of the comrades, and Sue shoots him dead. She is gratified and proud. The men then shoot Johnny-Boy and Sue. 
In this story, Sue faces several moral quandaries and challenges: (1) Does maintaining one's self-respect ever require one to risk serious physical harm, even death, to protest injustice; (2) should a black person give greater priority to black solidarity or to interracial working-class solidarity when these conflict; (3) is it always (or ever) permissible to give greater weight to the well-being of one's kin than to one's non-familial comrades and to the aim of achieving social justice; and (4) is it morally permissible to kill a traitorous comrade when failure to do so would set back irreparably the cause of social justice or leave one's loyal comrades vulnerable to grave harm?

There are no easy answers to these questions, and Wright does not suggest that the right choices in these circumstances are obvious, morally unambiguous, or without their tragic consequences. ${ }^{15}$ Nevertheless, he makes plain that calculations of personal advantage or a simple desire to avoid sacrifice and harm should not be decisive. He also makes clear that self-respect and solidarity are among the principal values to be considered in these moral deliberations. Finally, he emphasizes that servility and treachery are to be avoided even at a high cost to oneself. The ethics of cowardice and betrayal must be supplanted by a collectively shared ethics of defiance and solidarity.

15 The theme of tragedy is insightfully explored in P. Jay Delmar, “Tragic Patterns in Richard Wright's Uncle Tom's Children," Negro American Literature Forum 10 (1976): 3-12. Also see Edwin Berry Burgum, "The Art of Richard Wright's Short Stories," in Richard Wright: A Collection of Critical Essays, ed. Richard Macksey and Frank E. Moorer (Englewood Cliffs: Prentice-Hall, 1984), pp. 194-206. 


\section{JUSTICE, SOLIDARITY, AND SELF-RESPECT}

Wright's main characters should not be understood as moral archetypes. Unlike in Stowe's novel, there is no Christ-like figure. These are ordinary people, far from perfect. His stories do not depict individuals who fully or consistently embody the new militant ethic he prescribes. Many falter, some badly. In fact, the stories often show the tragic consequences that ensue when the oppressed fail to heed this ethic - a sort of cosmic sanction. And they represent vividly individuals who are caught between the old ethic and the new, struggling to overcome their dispositions to capitulate to injustice and to suffer indignities in silence. I think Wright's ethical judgments—so far as I can discern them—are, mostly, on the mark. My goal in the remainder of this essay will be to articulate and defend some general principles that can justify these judgments and to explain how these principles are related. I should note that in taking up this task I do not mean to imply that Wright would have endorsed the particulars of my account, though I do believe the account I offer preserves the spirit of his philosophical intervention.

\section{A. The Duty of Justice}

The duty of justice is a moral duty we are all bound by. Following Rawls's characterization, the duty of justice demands, most fundamentally, that we respect and support just institutions. ${ }^{16}$ When we fall under the jurisdiction of a just institutional framework, we fulfill this duty by complying with the institutions' rules

\footnotetext{
16 John Rawls, $A$ Theory of Justice, rev. ed. (Cambridge: Harvard University Press, 1999), pp. 99-100. Also see Jeremy Waldron, "Special Ties and Natural Duties," Philosophy \& Public Affairs 22 (1993): 3-30.
} 
and calling on others to do the same. Just institutions could not remain stable and just if individuals did not regard themselves as bound to respect and support them. Moreover, we could not reasonably complain about being treated unjustly if there were no general duty, binding on us all, to see to it that no one is so treated. In this way, the duty of justice is simply a corollary of the value of justice itself. Justice would be an empty ideal without it.

When an institution or institutional arrangement is seriously unjust, the duty of justice still has a claim on us. Perhaps its strongest demand is that we contribute to establishing just social arrangements and to reforming unjust ones. Obviously, the perpetrators of injustice should cease their immoral actions, reform their ways, and provide compensation to their victims. The burden to set things right naturally falls on them first and most heavily. Bystanders too, whether they are beneficiaries of the unjust regime or in no way complicit, should do their part to bring about justice. In addition, and contrary to what some might suppose, the oppressed should contribute to the reform effort, not simply out of self-interest, but because the duty of justice enjoins them to do so. To be sure, conditions of oppression, by their very nature, are forcibly imposed on the oppressed, and the oppressed may bear no responsibility for the injustices they endure. Nevertheless, the oppressed do have some freedom to determine how they will respond to these conditions-e.g., whether they will acquiesce or resist. And the duty to help correct injustices is binding regardless of who the victims are, whether others or oneself. The duty of justice, then, is the moral anchor that grounds the ethics of resistance. 
A somewhat weaker demand is that, as far as reasonably possible, we not actively lend support, by word or deed, to unjust regimes. Supporting unjust institutions can give these institutions legitimacy, effectively strengthening their power over the oppressed. We should therefore do all we can to avoid complicity with oppressive structures. This duty is not absolute, however, since it may sometimes be practically impossible to reduce the suffering of the oppressed without inadvertently helping to perpetuate an unjust social system. Buying a slave to set him or her free lends legitimacy to a slave regime by suggesting that it is morally permissible to buy and sell human beings. Yet, it may be the right thing to do, all things considered.

The weakest demand that the duty of justice imposes-and one that is all but inescapable-is that we not be indifferent to societal injustices. Even if we cannot make a positive contribution to social reform and cannot entirely avoid some complicity, we should at least care about injustice. When we show a lack of concern about ongoing injustices, we fail to value justice properly, fail to acknowledge its moral urgency and priority. Apathy in the face of injustice is a serious vice, for it allows oppressive relations to go unchallenged, enabling their continued existence. Despite having a strong personal interest in not being treated unjustly, the oppressed can sometimes exhibit this vice, for example, when they resign themselves to living under unjust conditions, regarding these conditions as "just the way thing are." Even when pessimism about positive social change is warranted, when the way forward with social reform is entirely unclear, passive acceptance of 
the status quo is not the only remaining option. One can still condemn the injustice and take advantage of low-cost opportunities to openly express one's principled opposition to it.

\section{B. The Solidarity of the Oppressed}

Again, the duty of justice binds each of us. Exactly what it would take to fulfill the duty, however, naturally depends on a given agent's concrete circumstances. I want to draw out the implications of this duty for the oppressed, those most severely burdened by an unjust social structure or regime.

If an individual member of an oppressed group seeks to reform his or her society, he or she will need to do so in concert with others. Reform efforts, even modest ones, generally encounter serious opposition. Though the oppressed are rarely completely powerless to alter their fate, the power advantages of dominant groups are typically considerable. Any attempt to alter these power relations, to correct an unjust system, will require oppressed individuals to form bonds of solidarity with one another. To be sure, third party bystanders can sometimes be enlisted in reform efforts, and there may even be members of the dominant group who will defect and come over to the side of the oppressed. Yet the most reliable allies will often be drawn from the oppressed group itself, given their personal stake in emancipation and their mutual understanding born of the shared experience of oppression. The general duty of justice is, I contend, the primary normative basis for such solidarity. 
Acting on the duty of mutual aid-that is, the duty to help the needy, vulnerable, and weak when you are able—can also forge bonds of solidarity among the oppressed. Such in-group mutual assistance is perfectly permissible, sometimes praiseworthy, and often vital. And it, too, has implications for the ethics of the oppressed. However, the duty of mutual aid should not be confused with the duty of justice, for what a person does to fulfill the one duty may not fulfill the other. In fact, widespread mutual aid among the oppressed is compatible with their active or passive acceptance of unjust conditions. The members of an oppressed group may work together for their mutual survival without aiming to remove or alter the forces that subjugate them.

Being the victims of an unjust system provides the oppressed with a distinctive and life-shaping shared experience. This common experience often leads them to identify strongly with one another. This special bond, this sense of "weness," characteristic of all solidarity groups, can lend strength to a morally based commitment to work jointly to achieve social justice. The fact that the fate of the oppressed is closely linked provides an additional, interest-based reason to commit to group solidarity. However, unlike what some have supposed, mutual recognition of shared interests and common experience among the oppressed is not all there is to solidarity. Shared interests and common condition matter, but ethical commitment is at least as significant.

Once one has undertaken a commitment of solidarity by, say, publicly identifying with the group and its struggle against oppression, the commitment 
comes with special ethical requirements. These requirements are not strictly derivable from the duty of justice. Solidarity, like love and friendship, is an ethical subsystem with its own normative structure. There are distinctive role obligations for the would-be comrade, just as there are for the would-be lover and friend. Specifically, solidarity requires fidelity to group goals and values, loyalty to group members, mutual trust, and special concern for group members. Let me say a brief word about each of these.

Different forms of group solidarity are distinguished not only by their criteria for group membership but also by the particular goals and values group members are jointly committed to. Blacks struggled together to bring down Jim Crow; women fought for the right to vote; and the working class pushed for a minimum wage. Each of these forms of solidarity was rooted, at least in part, in a commitment to social justice. Sue, for example, chooses to embrace interracial working-class solidarity because its aim is the liberation of vulnerable working people from economic exploitation and racial domination, and she distances herself from traditional Christian values insofar as she regards these as impediments to this goal.

If shared goals and values are the soul of solidarity, loyalty is its heart. One must be loyal to those one is working with, and on behalf of, to achieve social justice. One must also be loyal to the group's basic ideals, never betraying them for mere personal advantage. Though many are suspicious of the epithets "sellout" and "Uncle 
Tom," sometimes these harsh judgments are apt. ${ }^{17}$ Group members have a right, indeed they have a duty, to criticize publicly, and perhaps to sanction, members whom they believe have failed to live up to group commitments. Thus, Sue condemned and ultimately killed Booker, not simply out of revenge for his deception, but also out of her sense that he had betrayed a group to which she belonged and to which he had pledged allegiance. Moreover, her refusal to tell the sheriff about the place of the Party meeting or the identities of the comrades was motivated, not solely by loyalty to her son, but by her own sense of fidelity to the group she hoped to protect. Whether one believes that Sue's actions were ultimately justified or wise, her actions are intelligible in light of the value of loyalty to one's comrades and their just cause. ${ }^{18}$

It is mutual trust between group members that allows them to overcome collective action problems and to cooperate effectively. Johnny-Boy tries to explain to Sue the error of blanket mistrust of whites. He recognizes that without cultivating mutual trust, workers cannot develop the group-based power needed to resist their

\footnotetext{
17 Randall Kennedy helpfully examines uses and abuses of the charge of sellout, particularly with respect to black Americans, in his, Sellout: The Politics of Racial Betrayal (New York: Pantheon, 2008).

18 Some have mistakenly viewed Sue as mainly a maternal or "mammy" figure. See, for example, Sherley Anne Williams, "Papa Dick and Sister-Woman: Reflections on Women in the Fiction of Richard Wright," in Richard Wright: A Collection of Critical Essays, ed. Arnold Rampersad (Englewood Cliffs: Prentice Hall, 1995), pp. 63-82; and Sylvia H. Keady, "Richard Wright's Women Characters and Inequality," Black American Literature Forum 10 (1976): 124-128. However, this reading is not plausible. In twice refusing to give the Sheriff and his men "what they wanted" — namely, her willing submission and betrayal-she was remaining true to deeply held ethical principles, which cannot be adopted simply because of motherly love. Her actions cannot be reduced to maternal inclinations, either toward Johnny-Boy or Reva. Indeed, had such inclinations been dominant, she would have accepted the Sheriff's offer to reveal the names of party members in exchange for sparing Johnny-Boy's life. Though Wright is fairly criticized for his stereotypical and sexist depictions of black women (e.g., as weak, stupid, manipulative, apolitical, and sexually available), he should be given credit for portraying a black female character in Sue who is a political agent in her own right, a person who acts from moral conviction and out of genuine self-respect. For a more even-handed (though not uncritical) treatment of Wright's female characters (Sue in particular), see Cheryl Higashida, "Aunt Sue's Children: Re-viewing the Gender(ed) Politics of Richard Wright's Radicalism," American Literature 75 (2003): 395-425.
} 
oppressors. Such trust should not be blind, however; and it can be exploited, as the case of Booker illustrates. In addition, building trust among the oppressed can be especially difficult because oppression so often divides and instills fear. But generating some degree of trust is absolutely essential.

Special concern must be extended to those whom one is working with (or hopes to work with) in the joint effort, for all members must feel valued if group unity is to be sustained in the midst of serious adversity. This is not simply a matter of impartial concern for the welfare of others. This is partiality towards the members of a group with which one strongly identifies. Thus, Sue sacrifices her life out of special concern for the fate of Party members, whose lives and freedom would have been at risk had she not stopped Booker from revealing their names. In the absence of this solidaristic commitment, no one would expect her to give her life to protect them and she almost certainly would not have done so.

From the standpoint of justice, solidarity among the oppressed has mainly extrinsic value. That is, it is valuable for what it produces-namely, the power to effectively combat injustice. Where there are sufficient numbers and group cohesion, the oppressed can be a potent collective agent of positive social change. But I hasten to add that solidarity also has intrinsic value to those who share in it. ${ }^{19}$ Solidarity brings into being a community of individuals who regard one another as equals and who are bound to one another by their joint committed to justice. Yet even if they are unsuccessful in their collective effort to end or mitigate injustice,

\footnotetext{
${ }^{19}$ Lawrence Blum has rightly emphasized this point in his criticism of my previous work on solidarity. See his, “Three Kinds of Race-Related Solidarity," Journal of Social Philosophy 38 (2007): 53-72.
} 
they still have each other-the mutual concern, trust, loyalty, and empathy that solidarity entails. Such communal ties are valuable quite apart from their political usefulness.

\section{Self-Respect and Resistance to Injustice}

It is often said that the oppressed should, and sometimes do, resist the injustices perpetrated against them. This requirement to resist injustice has at least two distinct normative grounds, however. There is, as has been discussed, the duty of justice, which entails an obligation to try to end or lessen injustice or, at a minimum, to show enough moral concern to condemn serious societal injustices. The duty of justice can enjoin us to resist social injustice when such acts would, for example, embolden the oppressed to fight back against those who would dominate and exploit them; invite potential allies to join in the fight for justice; or make those with the power and inclination to halt injustices aware that injustices have occurred. Acts of resistance motivated by the duty of justice are intended as contributions to effecting a more justice society or world. The important thing to note here is that the duty of justice does not require active resistance if such measures would be ineffective or counterproductive in achieving justice.

There is also however the duty to respect oneself as a person, and this too can provide a reason to resist injustice. But what is self-respect? Rawls has given an 
influential answer. ${ }^{20}$ He claims that self-respect is (i) a secure conviction that one's conception of the good is worthwhile and (ii) confidence in one's ability to realize that conception. I do not deny the significance of this conception of self-respect for questions of social justice. On the contrary, I believe it to be vital. However, the sense of "self-respect" that I have in mind does not primarily concern self-esteem or self-efficacy. ${ }^{21}$ It does have to do with a person's sense of self-worth, just not in a way that is bound up with the person's particular chosen projects or his or her ability to achieve them.

To possess self-respect, in the sense that concerns me here, means recognizing oneself as an object of respect. In particular, it means viewing oneself as a moral agent and moral equal with all others and valuing oneself accordingly. ${ }^{22}$ Selfrespecting persons insist on receiving just treatment, for they firmly believe that in virtue of their moral status they are entitled to such treatment. They do not believe that they must earn this treatment, through, say, meritorious action or good character. They know that their capacity for moral agency alone is sufficient to establish their right to equal justice, and this conviction functions for them as an unshakeable basis of self-worth. ${ }^{23}$

\footnotetext{
20 Rawls, $A$ Theory of Justice, pp. 386-391.

21 For relevant criticisms of Rawls's approach to self-respect, see See Stephen L. Darwall, "Two Kinds of Respect," Ethics 88 (1977): 36-49; Laurence Thomas, "Rawlsian Self-Respect and the Black Consciousness Movement," Philosophical Forum 9 (1978): 303-314; David Sachs, "How to Distinguish Self-Respect from Self-Esteem," Philosophy and Public Affairs 10 (1981): 346-360.

22 See Thomas Hill, Jr., Autonomy and Self-Respect (Cambridge, UK: Cambridge University Press, 1991), chap. 1; and Bernard R. Boxill, Blacks and Social Justice, rev. ed. (Lanham, MD: Rowman \& Littlefield, 1992), pp. 186-199. 23 While the conception of self-respect defended here owes much to Kant, the reader should not take it that I am committed to Kant's metaphysics of the person. I follow Rawls in thinking of moral persons as rational agents who choose their own purposes in life and who are capable of a sense of justice. Such agents are living creatures in the natural world, not noumenal selves. The relevant sense of justice involves the capacity to understand what
} 
A strong sense of self-respect among the members of a society helps to sustain just institutions and to discourage injustice. Where institutional arrangements are not just, the self-respect of members provides them a reason to reform their institutions, for they will not be able to rest content until their rights are fully respected. Self-respect, like solidarity, is thus a key value in the ethics of the oppressed. On grounds of self-respect, the oppressed fight back against their oppressors, demanding the equal justice they know they deserve.

Yet, as with Sue's verbal protest against the sheriff and his men, which resulted in her being beaten, self-respect is not to be valued solely for the positive role it can play in sustaining or bringing about a just society. There is something to be said for resisting one's oppressors even when one knows that doing so will not end or lessen the injustice, will not reduce the suffering of the oppressed (and might even worsen it), and will bring with it significant personal cost or risk. In other words, a strong sense of self-respect is to be valued quite apart from its positive social consequences.

As Thomas Hill and Bernard Boxill have convincingly argued, the person who lacks self-respect fails to have the right attitude about his or her moral status. By being willing to accept, without complaint or protest, less than equal respect from others, such servile persons do not give morality the esteem it merits. To lack selfrespect is to fail to properly value one's moral rights. This broadly Kantian picture of

justice requires and the ability to freely confirm one's conduct to that understanding, capacities that any normal human being will have or develop. Moral persons have equal moral status in that they are, in virtue of their capacity for moral agency, entitled to equal justice. See Rawls, A Theory of Justice, pp. 441-449. 
self-respect focuses on the need to show respect for morality. But there are other reasons for the oppressed to preserve their self-respect.

Maintaining one's self-respect in the face of injustice is not simply about respecting the authority of morality. To focus exclusively on respecting moralitysay, through respect for moral personhood whether embodied in others or in oneself-would make the "self" incidental to the expression of respect. The sense of self-regard, of a personal stake in such respect, is inexplicable in such terms. A life without a healthy sense of self-respect is an impoverished life for the particular person whose life it is. Self-respect is about living with personal dignity, sometimes called "pride."24 Sometimes one has to defy illegitimate authority or to refuse to comply with unjust demands, even if such actions would produce no net reduction in oppression or suffering. ${ }^{25}$ Moral pride may demand it.

Acting from the motive of self-respect is not the same as acting from the motive of revenge-a distinction that Zora Neale Hurston elides in her harsh review of Wright's collection. ${ }^{26}$ The point is not to retaliate against or destroy those that have wronged you. The point is to preserve something invaluable in oneself-a secure sense of one's moral worth—without which one's life would be cause for shame or even self-loathing.

\footnotetext{
24 There is moral ambiguity in the word "pride." Pride can sometimes be a vice, as when it takes the form of arrogant self-satisfaction. But it can sometimes be a virtue, when for example it expresses an appropriate sense of one's value. Sue arguably exhibits both senses of pride, though commentators tend to emphasize the first only. 25 In this way, I disagree with Cudd's view that for an act to count as resistance to oppression the agent must intend that the act lessen the oppression. See Ann Cudd, Analyzing Oppression (Oxford: Oxford University Press, 2006), pp. 188-195.

26 Zora Neale Hurston, “Stories of Conflict," (Review of Uncle Tom's Children) Saturday Review of Literature 17 (April 2, 1938).
} 
Acting out of self-respect is also to be distinguished from acting out of selfdefense. Again, the motive is different. With self-defense, one acts to preserve one's very existence or to avoid physical harm. With self-respect, one acts to preserve one's pride, which may entail some personal cost. So, though Sue knows she will lose her son and even her own life, she takes satisfaction in knowing that, despite all her personal sacrifices, she has not lost her dignity. Thus, in maintaining one's selfrespect in the face of injustice one is holding onto something that is, in a sense, intangible but that is nevertheless crucial to a worthwhile life.

\section{Self-Respect as a Duty to Others}

Both Hill and Boxill seem to think of servility as a kind of personal vice or character flaw, one which others are not generally entitled to complain about, since it does not wrong them. On this view, self-respect is a duty to oneself, not to others. This position is, I think, basically correct. Some, however, are skeptical about the cogency of the idea of a duty to oneself, regarding such "duties" as mysterious. The skeptic might wonder why anyone should care, from a moral point of view, about maintaining his or her self-respect. Such a skeptic could concede that some persons feel that they cannot live without a strong sense of self-respect, that their lives would be severely diminished if this were lost. But the skeptic might nevertheless doubt that we have any basis for criticizing those who see little value in the preservation of moral pride. The skeptic might therefore insist that the maintenance of self-respect should not be regarded as an indispensible element of the ethics of 
the oppressed. I want to offer a brief and partial answer to this skeptic. My strategy will be to show that self-respect, at least under conditions of oppression, does have other-regarding dimensions. When one is a member of an oppressed group, maintaining one's self-respect is, in part, a duty to others.

Consider the traditional political culture of African Americans. When a black person levels the charge "Uncle Tom" against another black person, this could mean one of two things. The criticism could be that the accused has betrayed the group by violating the norms of solidarity. In other words, the alleged "Uncle Tom" is believed to have failed to hold firm to the group's fundamental values or goals; to have been disloyal to his fellow blacks; to have turned out to be an untrustworthy ally; or to have shown insufficient concern for the welfare of other blacks.

But the charge of "Uncle Tom" also has a meaning that, though otherregarding in its normative significance, does not imply betrayal. The criticism is that the alleged Uncle Tom is servile, the "cringing type" whose willful submission to humiliation and mistreatment is a sign that he has lost all respect for himself. This is certainly a character flaw, but it is the type of flaw that gives others who are vulnerable to similar mistreatment a group-based reason to criticize those who have the defect. When one suffers an injustice because one belongs to a group who is targeted for mistreatment qua group member (e.g., as a black person, a woman, or a Latino), this makes the preservation of one's self-respect other-regarding, for the failure to acknowledge that the treatment is unjust harms the interests of other group members. For example, blacks under the Jim Crow regime had a right to 
complain about the servility of an Uncle Tom, even to condemn it, since by downplaying or tolerating injustice the Uncle Tom communicated to others that the rights of blacks should not be taken seriously. Sending this kind of message-that, say, blacks are content with their subordinate social position-harms the vital interests of other blacks.

Moreover, a person who lacks a strong sense of self-respect cannot be regarded as a good ally, since her comrades would have reason to fear she'd sell them out when the going got tough. Recall that mutual trust is a core component of solidarity. A commitment to not surrender one's dignity simply to avoid personal loss or harm should therefore be regarded as a necessary condition for full standing in the solidaristic community. One has to be willing to make sacrifices to hold on to one's pride, not only to live a life worthy of one's moral status, but also to assure fellow group members that one won't let them down when faced with adversity. Thus, the maintenance of self-respect is in fact an indispensible part of the ethics of the oppressed.

\section{CONCLUSION}

From that standpoint of the ethics of the oppressed, not all betrayal and servility is morally culpable. These vices can be a consequence-whether an intended aim or byproduct—of the system of oppression itself. When a powerful oppressive regime exists for many years, say, over generations, the oppressed, losing all hope for liberation, may come to accommodate themselves to the injustices they suffer, no 
longer fighting back. Ignorance about the true source of their plight may be encouraged or maintained by denying them needed education. Indoctrination and propaganda can mislead the oppressed about their legitimate moral rights, suggesting that they are not in fact oppressed but free. The burdens of living with injustice can incline the oppressed to retreat from such unpleasant realities through diversion or fantasy—say, through drugs, sex, or religion. For example, indulging in religious ideas of heavenly bliss after death or of redemption through divine intervention, though no doubt having the power to console, can seem to the oppressed to relieve them of the duty to resist their oppressors. ${ }^{27}$ These vices, engendered by oppressive conditions, can prevent the oppressed from fulfilling or properly appreciating their duties of justice and self-respect. But the vices are still vices, and the duties remain duties, though the oppressed in such cases have legitimate excuses for these failings.

Wright was aware of these challenges, as his discussion of the ethics of Jim Crow attests. In dramatizing the ethics of the oppressed, he wanted to encourage blacks of the segregation era to shed their culture of betrayal and servility and to take up a more militant stance. But he knew that many, understandably, would find this incredibly difficult to do. Undoubtedly, heroic individuals, with a strong sense of justice and self-respect, had to step forward to model this new ethic and to inspire

\footnotetext{
27 Wright is clearly concerned that Christian faith can cause blacks to be passive and subservient, making them more susceptible to domination. However, he does not, in these stories at least, condemn Christianity per se. In fact, he often uses Christian imagery positively and draws parallels between the message of the Gospels and socialist principles. Perhaps he thought the change in moral consciousness that blacks needed to undergo would be made easier if he appealed to familiar ideas in Christianity. For discussion, see Edward Margolies, The Art of Richard Wright (Carbondale: Southern Illinois University Press, 1969), pp. 57-73.
} 
others to take action. But solidarity among the oppressed was just as important. Unity among the oppressed can often help subjugated persons find the courage to overcome their timidity. Successful collective action, rooted in a joint commitment to justice, has the power to repair a damaged sense of self-respect, reminding the oppressed of their moral agency and equal moral status. And, perhaps above all, such efforts can restore hope, which is essential, for despair makes the surrender to injustice seem inevitable.

These considerations lead me to posit, following Wright, that solidarity and self-respect are essential components of the ethics of the oppressed. Expressions of self-respect inspire and make solidarity possible; and acts of solidarity repair and nurture self-respect. Both make living with dignity under conditions of oppression much more likely. One can take pride, not only in defiantly standing alone, but also in standing with others in a righteous fight for justice. Solidarity and self-respect are also necessary for meaningful resistance to injustice. And if the group, despite its adversity, remains steadfast in its commitment to these values, it may, in the end, prevail. $^{28}$

\footnotetext{
28 For comments on previous drafts of this essay, I thank Arnold Davidson, Andrew Fine, Jessie Scanlon, and Werner Sollors. For feedback on public presentations of these ideas, I thank audiences at Northwestern University, University of Cape Town, University of Dayton, University of Pittsburgh, University of the Witwatersrand, Vanderbilt University, Yale University, the Collegium for African American Research Conference in Madrid, and the Richard Wright Centennial Conference in Paris.
} 